\title{
Sucrose in the diet of diabetic patients - just another carbohydrate?
}

\author{
D. B. Peterson ${ }^{1}$, J. Lambert ${ }^{1}$, S. Gerring ${ }^{1}$, P. Darling ${ }^{1}$, R. D. Carter ${ }^{1}$, R. Jelfs ${ }^{1}$ and J. I. Mann ${ }^{1,2}$ \\ ${ }^{1}$ Diabetes Research Laboratories and ${ }^{2}$ Department of Community Medicine and General Practice, Radcliffe Infirmary, Oxford, UK
}

\begin{abstract}
Summary. The effects of regularly eating sucrose were studied in 23 diabetic patients, 12 Type 1 (insulin-dependent) and 11 Type 2 (non-insulin-dependent), with differing degrees of glycaemic control. Two diets, each lasting 6 weeks, were compared in a randomised cross-over study. Both diets were high in fibre and low in fat. In one diet $45 \mathrm{~g}$ of complex carbohydrate was replaced by $45 \mathrm{~g}$ of sucrose taken at mealtimes. There were no significant biochemical differences between the two diets in either Type 1 or Type 2 patients. In Type 1 patients the mean ( \pm SEM) fasting plasma glucose was 10.5 (1.8) $\mathrm{mmol} / 1$ on the control diet and $10.3(1.5) \mathrm{mmol} / 1$ on sucrose. In Type 2 patients the levels were $9.1(0.8) \mathrm{mmol} / 1$ and $8.9(0.8) \mathrm{mmol} / 1$ respectively. Glycosylated haemoglobin for
\end{abstract}

the Type 1 patients was $9.9 \%$ on control and $10.3 \%$ on sucrose; for Type 2 patients the figures were $9.3 \%$ and $9.0 \%$ respective1y. There were no differences in mean daily plasma glucose levels or diurnal glucose profiles. Cholesterol (total and in lipoprotein fractions) was unchanged, as were diurnal triglyceride profiles and plasma insulin profiles in the Type 2 patients. There were no changes in medication or body weight. We conclude that a moderate amount of sucrose taken daily at mealtimes does not cause deterioration in metabolic control in diabetic patients following a high fibre/low fat diet.

Key words: Sucrose, carbohydrate, diabetic diet, metabolic control.
Sucrose and other refined carbohydrates are widely believed to cause unacceptably high rises in post-prandial blood glucose levels. Recent acute studies comparing sucrose and various individual starches, taken alone or as part of mixed meals, have failed to show significant differences in glycaemic response [1-4]. It is difficult for even the most careful diabetic patient to avoid sucrose, as it is found in so many foods. Most diabetic patients would welcome the possibility of selecting from a wider choice of foods without feelings of guilt or anxiety. There have not been any long term studies of sucrose use by unselected diabetic patients choosing their own foods. We report here the results of our study, where sucrose was eaten regularly in the context of a practical high carbohydrate/high fibre diet as currently recommended [5].

\section{Subjects and methods}

Twenty-three diabetic patients were recruited from the diabetic clinics in Oxford. Twelve were Type 1 (insulin-dependent) and 11 Type 2 (non-insulin-dependent); their characteristics are given in Table 1. Marked obesity (BMI $>28.0$ ), inability to supervise food intake and coexisting major illness were regarded as excluding factors for the study. The participants represented consecutively approached patients who were willing to follow the protocol. Twelve of those approached were unable to participate for personal reasons. None withdrew after commencing the study. All gave informed consent to the study, which had ethical committee approval.

Patients were individually assessed to determine daily energy requirements and to plan the two diets which they then took in random order, each lasting 6 weeks. The control diet $(\mathrm{Co})$ fulfilled current British Diabetic Association recommendations: fibre-rich complex carbo-

Table 1. Characteristics of patients

\begin{tabular}{|c|c|c|}
\hline & $\begin{array}{l}\text { Type } 1 \\
\text { (insulin- } \\
\text { dependent) }\end{array}$ & $\begin{array}{l}\text { Type } 2 \\
\text { (non-insulin- } \\
\text { dependent) }\end{array}$ \\
\hline Number & $\begin{array}{l}12 \text { (10 male, } \\
2 \text { female) }\end{array}$ & $\begin{array}{l}11 \text { ( } 7 \text { male, } \\
4 \text { female) }\end{array}$ \\
\hline Age $\pm S D$ (years) & $52 \pm 11$ & $56 \pm 9$ \\
\hline Duration of diabetes (years) & $18 \pm 11$ & $10 \pm 6$ \\
\hline $\begin{array}{l}\text { Mean (range) body mass } \\
\text { index }\left(\mathrm{kg} / \mathrm{m}^{2}\right)\end{array}$ & $24.9(21.2-27.9)$ & $24.7(20.1-28.0)$ \\
\hline $\begin{array}{l}\text { Mean (range) daily insulin } \\
\text { dose (U/ kg) }\end{array}$ & $0.65(0.30-0.96)$ & - \\
\hline $\begin{array}{l}\text { Oral hypoglycaemic } \\
\text { medication }\end{array}$ & - & $\begin{array}{l}5 \text { sulphonylurea } \\
\text { only } \\
6 \text { sulphonylurea } \\
\text { + metformin }\end{array}$ \\
\hline
\end{tabular}


Table 2. Typical daily menu plan

\begin{tabular}{|c|c|c|c|c|}
\hline \multirow[t]{2}{*}{ Meal } & \multicolumn{2}{|l|}{ Control diet } & \multicolumn{2}{|l|}{ Sucrose diet } \\
\hline & Food & $\begin{array}{l}\text { Weight } \\
\text { (g) }\end{array}$ & Food & $\begin{array}{l}\text { Weight } \\
\text { (g) }\end{array}$ \\
\hline Breakfast & $\begin{array}{l}\text { Weetabix } \\
\text { All bran } \\
\text { Wholemeal bread } \\
\text { Margarine }\end{array}$ & $\begin{array}{l}36 \\
14 \\
70 \\
11\end{array}$ & $\begin{array}{l}\text { Weetabix }^{\mathrm{a}} \\
\text { All bran } \\
\text { Wholemeal bread } \\
\text { Margarine } \\
\text { Marmalade }\end{array}$ & $\begin{array}{l}18 \\
20 \\
70 \\
12 \\
22\end{array}$ \\
\hline Snack & Digestive biscuits & 30 & Digestive biscuits & 30 \\
\hline Mid-day & $\begin{array}{l}\text { Cheddar cheese } \\
\text { Tomato } \\
\text { Lettuce } \\
\text { Cucumber } \\
\text { Wholemeal bread } \\
\text { Margarine } \\
\text { Apple }\end{array}$ & $\begin{array}{r}30 \\
80 \\
30 \\
30 \\
105 \\
8 \\
120\end{array}$ & $\begin{array}{l}\text { Cheddar cheese } \\
\text { Tomato } \\
\text { Lettuce } \\
\text { Cucumber } \\
\text { Wholemeal bread } \\
\text { Margarine } \\
\text { Apple } \\
\text { Toffees }\end{array}$ & $\begin{array}{r}30 \\
80 \\
30 \\
30 \\
70 \\
6 \\
120 \\
21\end{array}$ \\
\hline Snack & Digestive biscuit & 15 & Digestive biscuit & 15 \\
\hline Evening & $\begin{array}{l}\text { Lean roast pork } \\
\text { Cauliflower } \\
\text { Carrots } \\
\text { Haricot beans (dry } \\
\text { wt.) } \\
\text { Boiled potato } \\
\text { Banana } \\
\text { Custard powder } \\
\text { + art. sweetener }\end{array}$ & $\begin{array}{r}60 \\
60 \\
50 \\
50 \\
\\
150 \\
65 \\
8\end{array}$ & $\begin{array}{l}\text { Lean roast pork } \\
\text { Cauliflower } \\
\text { Carrots } \\
\text { Haricot beans } \\
\text { Boiled Potato } \\
\text { Banana } \\
\text { Custard powder } \\
\text { Sugar }\end{array}$ & $\begin{array}{r}60 \\
60 \\
50 \\
50 \\
\\
75 \\
65 \\
8 \\
15\end{array}$ \\
\hline Snack & $\begin{array}{l}\text { Wholemeal bread } \\
\text { Margarine } \\
\text { Tomato } \\
\text { Digestive biscuit }\end{array}$ & $\begin{array}{r}70 \\
8 \\
70 \\
15\end{array}$ & $\begin{array}{l}\text { Wholemeal bread } \\
\text { Margarine } \\
\text { Tomato } \\
\text { Digestive biscuit }\end{array}$ & $\begin{array}{r}70 \\
8 \\
70 \\
15\end{array}$ \\
\hline $\begin{array}{l}\text { Daily allov } \\
\text { milk }\end{array}$ & ance of skimmed & 445 & Skimmed milk & 445 \\
\hline
\end{tabular}

a Foods altered to maintain constant carbohydrate and fibre content

Table 3. Daily energy intake from major nutrients. Means \pm SD for 23 patients

\begin{tabular}{|c|c|c|}
\hline Nutrient & Control diet & Sucrose diet \\
\hline Energy kcal & $1910 \pm 396$ & $1910 \pm 396$ \\
\hline Carbohydrate (\%) & $53 \pm 1$ & $54 \pm 2$ \\
\hline Simple sugars (\%) & $10 \pm 1$ & $18 \pm 1$ \\
\hline $\begin{array}{l}\text { Ratio simple: complex } \\
\text { carbohydrate }\end{array}$ & $1: 5$ & $1: 2$ \\
\hline Fat (\%) & $27 \pm$ & $27 \pm 3$ \\
\hline Protein $(\%)$ & $20 \pm 2$ & $19 \pm 2$ \\
\hline Fibre $(\mathrm{g})$ & $57.5 \pm 13.4$ & $53.5 \pm 13.6$ \\
\hline
\end{tabular}

Values are expressed as mean $\pm \mathrm{SD}$

hydrate provided $50-55 \%$ total energy, and fat about $30 \%$. In the sucrose diet $(\mathrm{Su})$ approximately $45 \mathrm{~g}$ complex carbohydrate was replaced by $45 \mathrm{~g}$ sucrose daily, taken in foods at the 3 main mealtimes. Minor adjustments were made to maintain other nutrients, including fibre, as constant as possible. Patients were given a sucrose exchange list of 15-g portions and a booklet of recipes using high fibre foods in addition to detailed instruction by a dietitian (JL). Typical daily menus are shown in Table 2. On Su, carbohydrates such as bread and potatoes were reduced and fibre-rich cereals encouraged to maintain dietary fibre. Rich sources of soluble fibre, such as dried beans, remained constant throughout. Table 3 shows the mean intakes of major
Table 4. Indices of glycaemic control from diurnal profiles for 12 Type 1 (insulin-dependent) diabetic patients

\begin{tabular}{lcc}
\hline Measure & Control diet & Sucrose diet \\
\hline Plasma glucose (mmol/1) & & \\
Fasting & $10.5(1.8)$ & $10.3(1.5)$ \\
Preprandial $^{\mathrm{a}}$ & $10.5(1.3)$ & $10.0(1.3)$ \\
Incremental mean $^{\mathrm{b}}$ & $3.3(0.7)$ & $3.7(0.8)$ \\
Mean daily & $11.4(1.0)$ & $11.4(1.2)$ \\
HbA1 (\%) & $9.9(0.3)$ & $10.3(0.6)$ \\
\hline
\end{tabular}

a Mean of 3 meals and 3 snacks, ${ }^{b}$ mean of increments for $2 \mathrm{~h}$ after breakfast and lunch. Values are expressed as mean \pm SEM

Table 5. Indices of glycaemic control from diurnal profiles for 11 Type 2 (non-insulin-dependent) diabetic patients

\begin{tabular}{lcc}
\hline Measure & Control diet & Sucrose diet \\
\hline Plasma glucose (mmol/1) & & \\
Fasting & $9.1(0.8)$ & $8.9(0.8)$ \\
Preprandial $^{\mathrm{a}}$ & $8.9(0.8)$ & $9.1(0.9)$ \\
Incremental mean $^{\mathrm{b}}$ & $3.0(0.5)$ & $3.3(0.6)$ \\
Mean daily & $10.2(1.0)$ & $10.4(1.1)$ \\
HbA1 (\%) & $9.3(0.6)$ & $9.0(0.5)$ \\
\hline
\end{tabular}

a Mean of 3 meals and 3 snacks; $b$ mean of increments for $2 \mathrm{~h}$ after breakfast and lunch. Values are expressed as mean \pm SEM

nutrients on the 2 diets and the changes in intakes of sugars. The mean (range) intake of total simple sugars (both refined and naturally-occurring) increased from $49 \mathrm{~g}$ (30-81 g) daily on Co to $92 \mathrm{~g}(68-118 \mathrm{~g})$ on Su. After instruction in each diet, patients had a follow-up interview with the dietitian at 1 week. Dietetic advice was available throughout, with contact depending on both the patients' requests and the dietitian's assessment of their understanding of the diets. Patients provided the dietitian with a record of all food and drink consumed during a 3-day period in the second week, based on household measures or actual weighing whenever possible. This was used to verify their understanding of and compliance with the diets. A further detailed interview with the dietitian at the end of each period was used to provide an indication of overall acceptability and compliance.

At the end of each diet patients attended the day ward fasting and before taking their medication. An intravenous teflon cannula was inserted and blood was drawn for glucose, glycosylated haemoglobin (HbA1), total cholesterol and cholesterol subfractions and triglycerides. They were given three main meals and three snacks during the day, and blood was drawn hourly for $12 \mathrm{~h}$, except for half-hourly samples taken for $2 \mathrm{~h}$ after breakfast and lunch. All were analysed for glucose and triglycerides; in addition, insulin was measured throughout in the Type 2 diabetic patients. Both profile day menus were identical in energy content and nutrient distribution, but contained foods appropriate to the diet period just completed, as shown in Table 2.

Plasma glucose was measured by a standard glucose oxidase method ('GOD-Perid', Boehringer) on a Pye Unicam AC1 autoanalyser, $\mathrm{HbA} 1$ by electroendosmosis ('Glytrac', 5.0-8.2\% normal range, Corning), total cholesterol and subfractions by a standard enzymatic technique ('CHOD-PAP', Boehringer) following precipitation with heparin, manganese chloride and sodium dodecyl sulphate $[6,7]$ and total triglycerides following enzymatic hydrolysis. Plasma insulin was measured by a radioimmunoassay technique following charcoal separation of free and bound fractions [8].

\section{Statistical analysis}

Differences between the two profiles were statistically analysed using Student's t-test for paired data. 

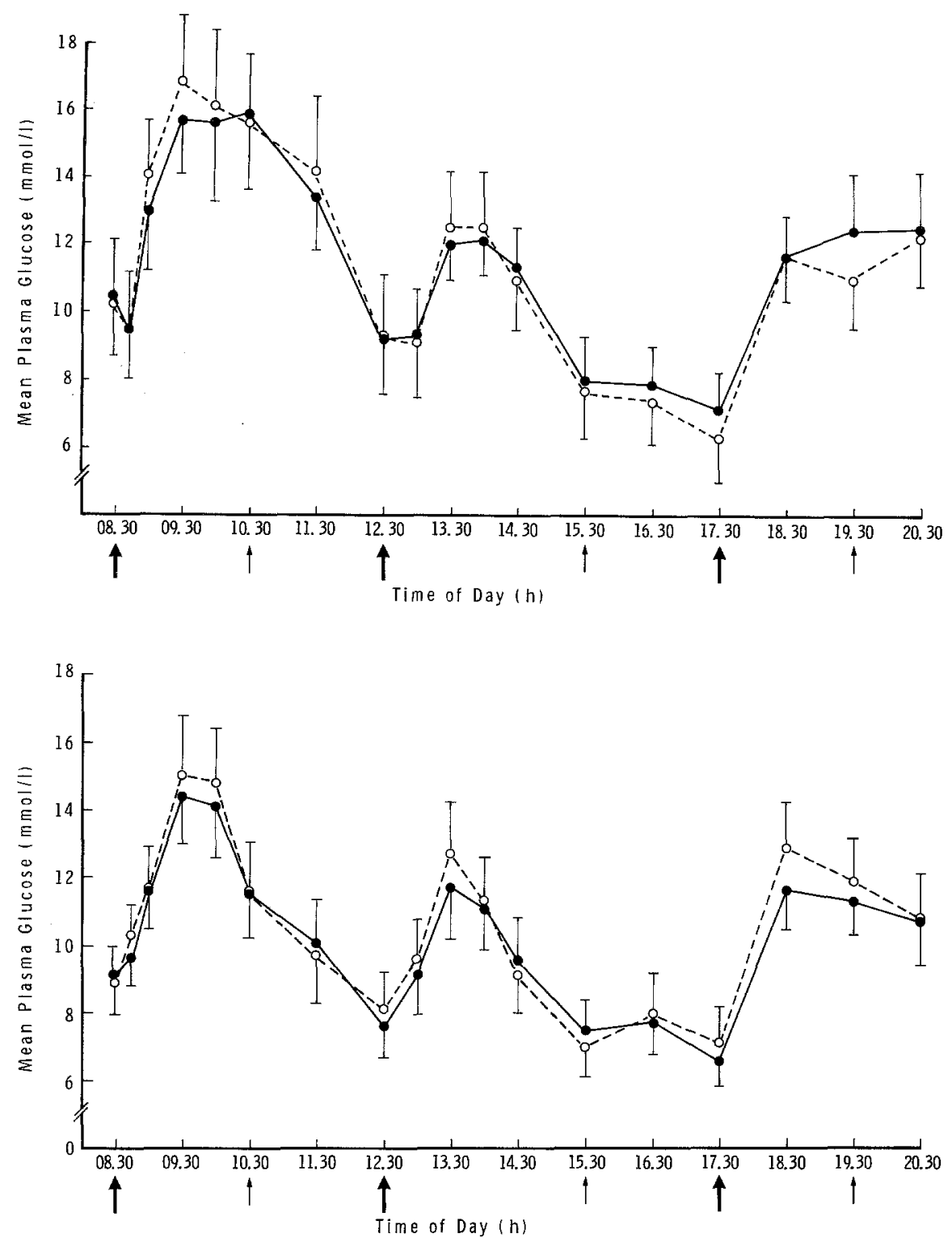

Fig. 1. Mean ( \pm SEM) diurnal plasma glucose values during profiles for 12 Type 1 (insulin-dependent) diabetic patients. - Control diet; O-...-O sucrose diet; $\uparrow$ large meal; $\uparrow$ snack
Fig. 2. Mean ( \pm SEM) diurnal plasma glucose values during profiles for 11 Type 2 (non-insulin-dependent) diabetic patients. Control diet; $\mathrm{O}^{----O} \mathrm{O}$ sucrose diet; $\uparrow$ large meal; $\uparrow$ snack

\section{Results}

There were no significant differences between the variables measured during profiles after the two diets in either Type 1 or Type 2 patients. Plasma glucose profiles were the same and are shown in Figures 1 and 2. A summary of various glycaemic indices is shown for Type 1 patients in Table 4 and for Type 2 patients in Table 5. There were no differences between fasting plasma glucose, mean preprandial or mean daily glucose levels. Mean postprandial increments for $2 \mathrm{~h}$ after breakfast and lunch were not significantly different. HbA1 levels were unchanged. Fasting lipid values are shown in Table 6; mean diurnal triglyceride values were the same on both diets (Type 1, $2.0 \pm 0.3 \mathrm{mmol} / 1$; Type 2, $2.3 \pm 0.3 \mathrm{mmol} / 1)$.

Body weight remained constant after the two diets, with the means ( \pm SEM) for Type 1 being $73.9(2.4) \mathrm{kg}$ on $\mathrm{Co}$ and 74.0 (2.4) $\mathrm{kg}$ on Su, and for Type 2 being 73.5
Table 6. Fasting blood lipid fractions after each diet

\begin{tabular}{llllll}
\hline & \multicolumn{2}{l}{ Type 1 patients } & & \multicolumn{2}{c}{ Type 2 patients } \\
\cline { 2 - 3 } & Control & Sucrose & & Control & Sucrose \\
\hline Total cholesterol & $4.8(0.3)$ & $4.9(0.3)$ & & $5.1(0.3)$ & $5.3(0.4)$ \\
HDL cholesterol & $1.3(0.1)$ & $1.3(0.1)$ & & $1.3(0.1)$ & $1.4(0.1)$ \\
LDL cholesterol & $3.0(0.3)$ & $3.0(0.3)$ & & $3.0(0.3)$ & $3.4(0.4)$ \\
VLDL cholesterol & $0.5(0.1)$ & $0.7(0.2)$ & & $0.7(0.2)$ & $0.4(0.1)$ \\
Total triglycerides & $1.5(0.2)$ & $1.7(0.2)$ & & $1.8(0.2)$ & $1.7(0.2)$ \\
\hline
\end{tabular}

Means $( \pm$ SEM) all in $\mathrm{mmol} / \mathrm{l}$

(2.9) $\mathrm{kg}$ on Co and $73.8(2.7) \mathrm{kg}$ on $\mathrm{Su}$. The average daily insulin dose was unchanged at $0.65 \pm 0.12 \mathrm{U} / \mathrm{kg}$ on $\mathrm{Co}$ and $0.66 \pm 0.12 \mathrm{U} / \mathrm{kg}$ on Su. Several patients chose to temporarily adjust their insulin dose up or down by a few units in response to hypoglycaemic episodes, but there were no significant long-term alterations in total dose or in distribution through the day. Type 2 patients 
had no changes in oral medication, and their fasting and mean daily insulin levels were similar on Co $(8 \pm 1 \mathrm{mU} / 1$ and $28 \pm 3 \mathrm{mU} / \mathrm{l})$ and $\mathrm{Su}(9 \pm 2 \mathrm{mU} / \mathrm{l}$ and $28 \pm 3 \mathrm{mU} / \mathrm{l})$.

\section{Discussion}

This study reports the effects of incorporating a realistic amount of sucrose in the diet of a group of diabetic patients attending a routine diabetic clinic. Previous investigations have been limited either to acute studies of sugars and starches, taken individually or in mixed meals [1-4, 9], or else have been carried out in highly selected groups of patients sometimes given up to $220 \mathrm{~g}$ sucrose daily $[10,11]$. We did not find any metabolic deteriorations when $15 \mathrm{~g}$ of sucrose, taken three times daily, replaced an isocaloric amount of complex carbohydrate over a 6-week period. Both control and experimental diets were high in fibre and low in fat. The amount of sucrose consumed approximately doubled the average daily intake of total simple sugars. Glycaemic profiles and blood lipids were similar after Co and $\mathrm{Su}$ in both Type 1 and Type 2 patients.

Our results are not so surprising when considering the results of studies comparing the acute metabolic effects of sucrose, other sugars and starches in diabetic patients. Bantle et al. [1] did not find any differences between sucrose and potato or wheat starches taken as part of a mixed meal. Fructose had a much smaller glycaemic effect and glucose the largest response of all. Lean et al. [2] treated diabetic patients to marmalade with breakfast and found the same glycaemic response when it was replaced by an isocaloric amount of bread. Hollenbeck et al. [12] varied the proportions of complex and simple carbohydrates from foods in the diet for 24- $\mathrm{h}$ periods and found similar glucose and insulin responses. Slama et al. [3] gave meals containing either added sucrose or rice starch to Type 1 patients monitored on the artificial pancreas and also found similar effects. Jenkins et al. [13] had earlier shown in their studies of the glycaemic response to various $50 \mathrm{~g}$ carbohydrate food portions in nondiabetic subjects that sucrose had only $59 \%$ of the effect of glucose. A review paper has suggested that the glycaemic response for sucrose is $86 \%$ that of white bread [14]. This figure is based on several studies, one of which was carried out in diabetic subjects.

These studies support the concept that, at least in certain circumstances, sucrose can be considered as just another carbohydrate. However, the ultimate test of acceptability of sucrose in the diabetic diet can only come from longer term studies. Only two other investigations have been undertaken, one in near-normoglycaemic patients with Type 1 diabetes controlled on insulin pumps [10] and the other in hypertriglyceridaemic diabetic patients with variable degrees of control and treated by diet alone [11]. Neither showed any deleterious ef- fects of sucrose, even in large amounts [11], but the results clearly cannot be generally applied.

In our study we offered patients a free choice of foods within the constraints of a high fibre/low fat diet similar to that recommended for all diabetic patients. The only specific condition was that during the period on $\mathrm{Su}$ they take three $15 \mathrm{~g}$ sucrose portions daily at mealtimes. A major difficulty in a study of this kind is knowing whether the subjects complied with the dietary advice. The three day dietary records supplemented by an interview at the end of each dietary period suggested a high level of compliance and satisfaction with a diet relatively high in fibre-rich carbohydrate (including various cooked dried beans) and low in fat. Many of the subjects were diabetic patients of long standing, and they found some initial difficulty adding sucrose to their diet. They all appear to have made the requested changes and enjoyed the freedom of having a modest amount of sucrose. It is also difficult when interpreting negative findings to be confident that a different trend would not have emerged had larger numbers been included. However, our study was calculated to be large enough to detect a deleterious effect of sucrose. The consistent findings in all subgroups suggest that a diet containing approximately $45 \mathrm{~g}$ of sucrose (around 18\% total daily energy) can safely be taken by both insulindependent and non-insulin-dependent diabetic patients, regardless of their degree of glycaemic control.

Despite these findings, we would urge caution with regard to several points. First, the background diet may be particularly important. Our findings apply only to those eating a high carbohydrate/high fibre/low fat diet and may not be applicable to those diabetic patients still following the old low carbohydrate dietary advice. Secondly, moderate amounts of sucrose can only be taken as a replacement for some complex carbohydrate and not as additional carbohydrate. We replaced commonly used complex carbohydrate foods with a relatively high glycaemic index like bread and potato, and left unchanged those with a low glycaemic index which are rich in soluble fibre. Finally, many diabetic patients, especially those with Type 2 diabetes, are overweight; for them, restriction of all energy-dense foods (fat and sucrose) should be recommended. The amount of sugar provided on the sucrose diet in this study was well below the national average. However, there can be little doubt that permitting a modest intake of sucrose can enhance palatability, and this may aid long-term compliance to a high fibre/low fat diet. Such diets have been shown to improve diabetic control and may reduce the risk of long-term vascular complications.

\footnotetext{
Acknowledgements. DBP was a Medical Research Council Training Fellow. We thank Drs. TDR Hockaday and A. Knight for permission to include patients under their care and are grateful to them and Dr. R.C.Turner for advice and encouragement. Ms. M. Burnett carried out the insulin assays, Ms. S. Lousley helped with diet planning and Ms. A. Reeve typed the manuscript.
} 


\section{References}

1. Bantle JP, Laine DC, Castle GW, Thomas JW, Hoogwerf BJ, Goetz FC (1983) Postprandial glucose and insulin responses to meals containing different carbohydrates in normal and diabetic subjects. N Engl J Med 309: 7-12

2. Lean MEJ, Tennison BR, Williams DRR (1985) Glycaemic effect of bread and marmalade in insulin-dependent diabetes. Diabet Med 2: 117-120

3. Slama G, Haardt MJ, Jean-Joseph P, Costagliola D, Goicolea I, Bornet F, Elgrably F, Tchobroutsky G (1984) Sucrose taken during mixed meal has no additional hyperglycaemic action over isocaloric amounts of starch in well-controlled diabetics. Lancet 2: 122-125

4. Bornet F, Haardt MJ, Costagliola D, Blayo A, Slama G (1985) Sucrose or honey at breakfast have no additional acute hyperglycaemic effect over an isoglucidic amount of bread in Type 2 diabetic patients. Diabetologia 28:213-217

5. British Diabetic Association (1982) Dietary recommendations for diabetics for the 1980s. Hum Nutr Appl Nutr 36: 378-386

6. Burstein M, Scholnik HR, Morfin R (1970) Rapid method for the isolation of lipoproteins from human serum by precipitation with polyanions. J Lipid Res 11: 583-595

7. Ononugbu IC, Lewis B (1976) Lipoprotein fractionation by a precipitation method. A simple quantitative procedure. Clin Chim Acta $71: 397-402$

8. Albano JDM, Ekins RP, Maritz G, Turner RC (1972) A sensitive, precise radioimmunoassay of serum insulin relying on charcoal separation of bound and free hormone moieties. Acta Endocrinol 70: 487-509
9. Akgun S, Ertel N (1980) A comparison of carbohydrate metabolism after sucrose, sorbitol and fructose meals in normal and diabetic subjects. Diabetes Care 3: 582-585

10. Chantelau EA, Gösseringer G, Sonnenberg GE, Berger M (1985) Moderate intake of sucrose does not impair metabolic control in pump-treated diabetic out-patients. Diabetologia 28: 204-207

11. Jellish WS, Emanuele MA, Abraira C (1984) Graded sucrose/carbohydrate diets in overtly hypertriglyceridaemic diabetic patients. Am J Med 77: 1015-1022

12. Hollenbeck CB, Coulston AM, Donner CC, Williams RA, Reaven GM (1985) The effects of variations in percent of naturally occurring complex and simple carbohydrates on plasma glucose and insulin responses in individuals with non-insulin dependent diabetes mellitus. Diabetes 34: 151-155

13. Jenkins DJA, Wolever TMS, Taylor RH, Barker $H$, Fielden $H$, Baldwin JM, Bowling AC, Newman HC, Jenkins AL, Goff DV (1981) Glycaemic index of foods: a physiological basis for carbohydrate exchange. Am J Clin Nutr 34:362-366

14. Jenkins DJA, Wolever TMS, Jenkins AL, Josse RG, Wong GS (1984) The glycaemic response to carbohydrate foods. Lancet 2: 388-391

Received: 15 October 1985

and in revised form: 27 January 1986

Dr. J. I. Mann

Gibson Laboratories Building

Radeliffe Infirmary

Oxford OX2 6HE

UK 